\title{
Chemical composition of glass and crystalline phases in coarse coal gasification ash
}

\author{
R.H. Matjie ${ }^{\mathrm{a}, \mathrm{b}}$, Zhongsheng Lic ${ }^{\mathrm{c}}$, Colin R. Ward ${ }^{\mathrm{c}}$ and David French ${ }^{\mathrm{d}}$
}

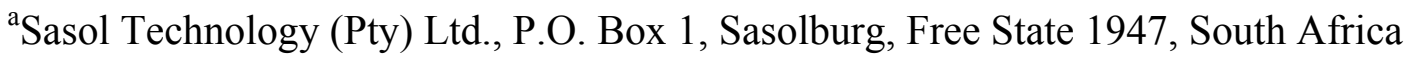

${ }^{b}$ Department of Materials Science and Metallurgical Engineering, University of

Pretoria, Pretoria 0002, South Africa

${ }^{\mathrm{c} S}$ School of Biological, Earth and Environmental Sciences, University of New South

Wales, Sydney, NSW 2052, Australia

${ }^{\mathrm{d}}$ CSIRO Energy Technology, PMB 7, Menai, NSW 2234, Australia

\section{Abstract}

A procedure has been developed for determining the chemical composition and relative abundance of the amorphous or glassy material, as well as crystalline phases, present in coarse coal gasification ash, in order to assist in predicting the behaviour of the material in cement/brick/concrete applications. The procedure is based on a combination of quantitative X-ray diffraction (XRD), chemical analysis and electron microprobe studies. XRD analysis indicates that the clinker samples contain a number of crystalline high temperature phases, including anorthite, mullite, cristobalite, quartz and diopside.

Quantitative evaluation using Rietveld-based techniques has been used to determine the percentages of both the individual crystalline phases and the glass component. These data were then combined with the chemistry of the crystalline phases and the overall chemical composition of the ash to estimate the chemical composition of the glass phase, which is typically the most abundant component present in the different materials.

Although there is some degree of scatter, comparison between the inferred glass composition from XRD and bulk chemistry and actual data on the glass composition using electron microprobe techniques suggest that the two approaches are broadly 
consistent. The microprobe further indicates that a range of compositions are present in the glassy and crystalline components of the ashes, including $\mathrm{Si}-\mathrm{Al}$-rich glass, metakaolin and $\mathrm{Fe}-\mathrm{Ca}-\mathrm{Mg}-\mathrm{Ti}$ phases, as well as quartz, anorthite and an aluminophosphate material. Electron microprobe and XRD studies also show that pyrrhotite (FeS), representing a high temperature transformation product of pyrite, is present in some clinker and partially burnt carbonaceous shale samples.

\section{Article Outline}

1. Introduction

2. Materials and methods

3. Results and discussion

3.1. Mineral matter in feed coal

3.2. Chemical composition of bulk gasification ash, heated stone and clinker samples 3.3. Mineralogy of bulk gasification ash and clinker samples

3.4. Interpretation of glass composition from $\mathrm{XRD}$ and chemical data

3.5. Determination of glass and mineral compositions by electron microprobe analysis

3.5.1. Quartz and feldspar crystals

3.5.2. Aluminosilicate glass

3.5.3. Other particles and phases

4. Conclusions

Acknowledgements

References

\section{Introduction}

The feed to the Sasol-Lurgi fixed-bed dry-bottom (FBDB) gasifiers used by Sasol in South Africa for coal gasification (Fig. 1) consists mainly of coarse (>6 mm) low grade, medium rank $\mathrm{C}$ (bituminous) coal and extraneous rock fragments (usually carbonaceous shale, siltstone, sandstone and mudstone). This feedstock is processed in the gasifiers at elevated temperatures (greater than $1350{ }^{\circ} \mathrm{C}$ ) and pressures (greater than 20 bar) to produce synthesis gas (also referred to as syngas), which is a mixture of carbon monoxide 
and hydrogen. Coal gasification ash is a major by-product of the gasification process [1]. This ash, referred to as 'coarse ash', is a combination of red and white to grey sintered clinkers with heterogeneous texture varying from fine material to large irregularly shaped aggregates of sizes ranging from $4 \mathrm{~mm}$ to $75 \mathrm{~mm}$.

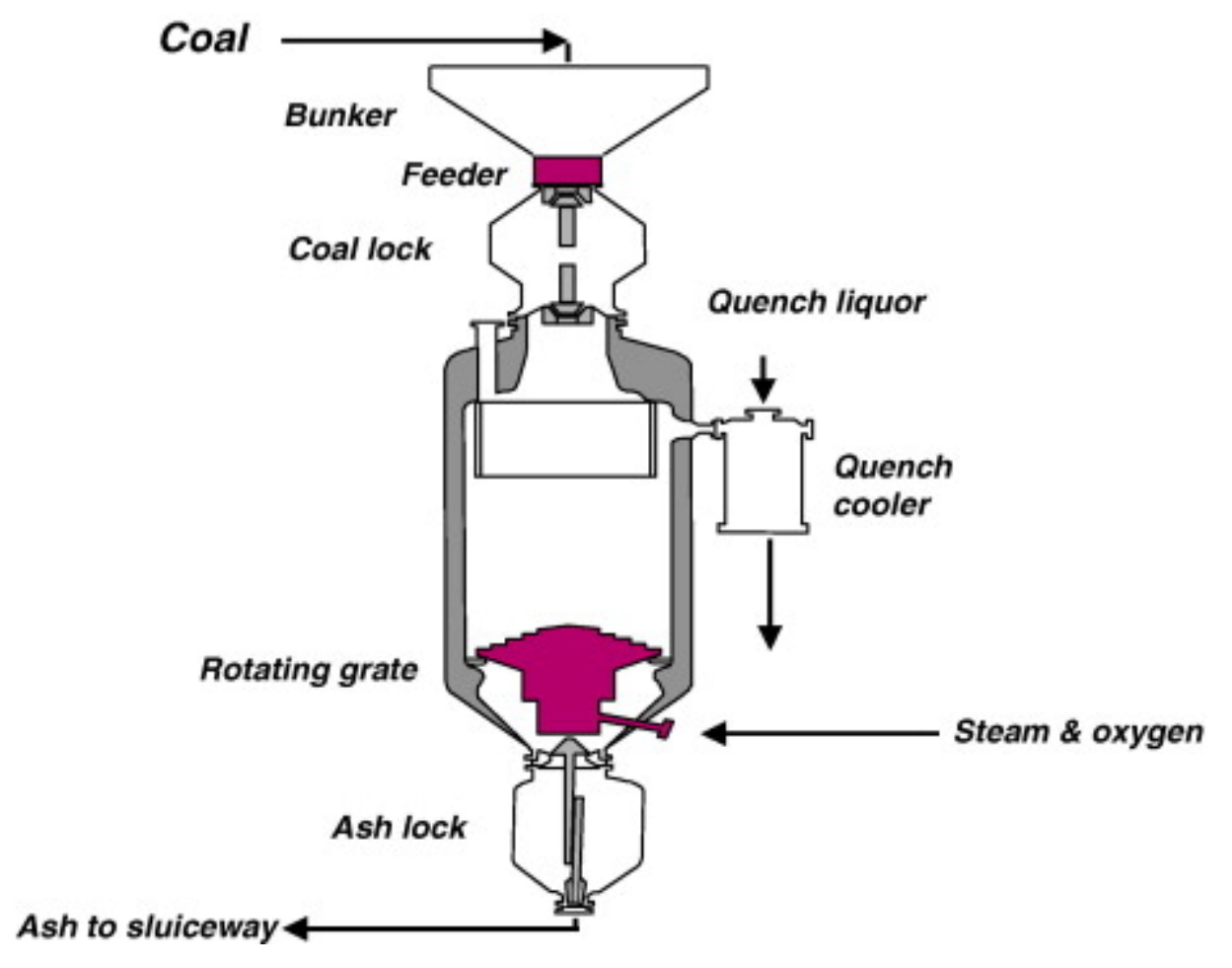

Fig. 1. Sasol-Lurgi fixed bed dry bottom (FBDB) gasifier.

Coal consists of organic matter (macerals) together with different types of inorganic constituents; the latter consisting of both minerals and non-mineral inorganic elements [2]. The non-mineral inorganic components typically include $\mathrm{Ca}, \mathrm{Mg}, \mathrm{Na}$ and other elements occurring as dissolved salts in the pore waters, as exchangeable ions attached to carboxylates and other functional groups, and organometallic complexes forming part of the organic matter. During gasification at elevated temperatures (greater than $1350^{\circ} \mathrm{C}$ ) and pressures (greater than 20 bar), a large part of the fluxing minerals/non-mineral inorganic elements in the coal mineral matter tends to partially melt and form liquid phases. These partly crystallise on cooling to form a number of different mineral phases occurring in association with a glassy component. 
Sintering refers to a process of softening and surface flow of particles; this occurs due to partial melting of the particle surface, causing particles to cling together. In most cases, sintered clinker particles are formed when fluxing elements such as $\mathrm{Ca}, \mathrm{Fe}^{2+}$ and $\mathrm{Mg}$ from coal mineral matter reduce the fusion temperature of aluminium silicates (clays) to temperatures ranging from 900 to $1200^{\circ} \mathrm{C}$ and form a partial melt. The heated rock fragments are cemented by this melt during the coal gasification process. In other instances, rock fragments (coal stones) in the feed, as well as trace amounts of unburnt carbon particles are encapsulated by the partial melt [1]. Although it does not presently occur in the Sasol-Lurgi gasification process, slagging causes partial or complete melting of the whole particle, to form a melt which, on cooling, produces a fused slag. Bryers [3], Srinivasachar et al. [4] and [5], Attalla et al. [6] and Van Alphen [7] found that liberated or excluded minerals are exposed to more oxidizing conditions during combustion than included minerals; this may enhance the rate of fusion, enlarge the clinker size, and also reduce the volatilization of inorganic elements during coal combustion. The non-liberated or included minerals generally reach peak temperatures in excess of the surrounding gas temperature, react quickly by coalescence due to their close proximity to one another, and may have lower melting points [6]. Some inorganic species in heated particles of included minerals may undergo reduction and start to volatilize and form sub-micron particles or gases when the remaining char burns.

Briggs and Lindsay [8] studied samples of pure minerals, including clays, pyrite and calcite, to identify components responsible for slagging when they transform at elevated temperatures. They found that a mixture of either illite or montmorillonite in the presence of pyrite and calcite forms a molten solution at temperatures of around $600-650{ }^{\circ} \mathrm{C}$. If the illite or montmorillonite is totally replaced by kaolinite, however, the liquid forms at $750-760^{\circ} \mathrm{C}$. XRD analysis of quenched samples in such cases indicates the presence of pyrrhotite $\left(\mathrm{Fe}_{7} \mathrm{~S}_{8}\right)$, quicklime $(\mathrm{CaO})$ and oldhamite $(\mathrm{CaS})$. The researchers also found that the clay structure reacted with the partially-oxidized pyrite to form silicate glass.

Many researchers have indicated that the proportion of glass in coal fly ash, as well as the glass composition, may play an important role in initiating pozzolanic reactions in the production of slag-portland cement concrete and bricks [9] and [10]. The glass content 
also significantly affects the strength of slags [9]. Knowledge of the glassy fraction is therefore important in understanding more fully aspects of coal gasification ash behaviour, as well as the development of sintered ash particles in gasification systems. The main objective of the present study was to use recently-developed analytical techniques to investigate the nature and abundance of the mineral and glass phases present in coarse gasification ash (hand-picked clinkers and heated stone particles) from the Sasol process, as well as to evaluate the chemical composition of the different components, including both the minerals and the glass, and if possible to identify their relation to the mineral matter in the feed coal. The principal technique used was quantitative X-ray diffraction, including procedures to evaluate amorphous components in coal ash described by Ward and French [11], along with bulk chemical analysis, optical microscopy and electron microprobe investigations.

\section{Materials and methods}

Samples of "turnout" test material were taken from Sasol-Lurgi fixed-bed dry-bottom (FBDB) Gasifier Number 41, using the sampling procedure developed by Bunt [12]. A number of different clinker particles and partially burned carbonaceous shale fragments were selected from the coal gasification ash (Fig. 1) on the basis of their colour and size. Thin sections, polished sections and polished thin sections were prepared from these particles for optical and electron microscope studies. Selected polished thin sections were further analysed in a Cameca SX-50 electron microprobe, using procedures described by Patterson et al. [13].

On a hand-specimen scale many of the samples contained partly burnt carbonaceous shale and other rock fragments, set in a fine-grained glassy matrix (Fig. 2, top left). The fragments commonly showed reaction rims around the contact with the matrix, developed as they became incorporated into the clinker while moving through the gasifier bed. Under the microscope some fragments still displayed their original sedimentary texture, with granular silt- and sand-sized particles surrounded by partly fused matrix material (Fig. 2, top right). The matrix containing these fragments was seen under the microscope 
to consist mainly of elongate feldspar crystals, set in a very fine-grained, essentially glassy vesicular groundmass (Fig. 2, bottom left and right).
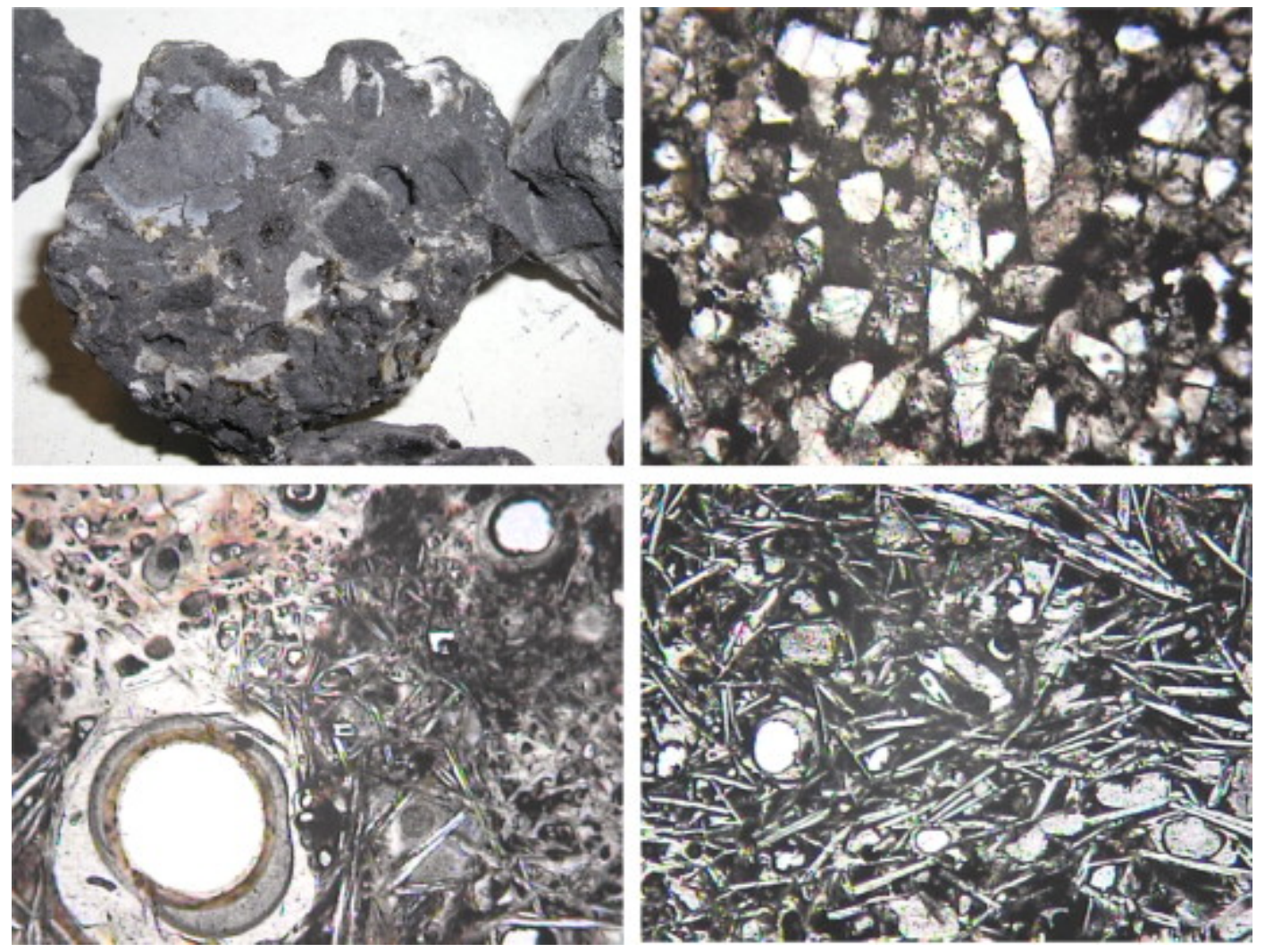

Fig. 2. Textures of clinker materials. (Top left) Clinker fragment from gasifier (width approximately $7 \mathrm{~cm}$ ), showing partly burnt carbonaceous shale particles with lightcoloured reaction rims, set in a fine sintered to glassy matrix. Other images: thin-section photomicrographs (open polars, field width $1.4 \mathrm{~mm}$ ) of detrital quartz grains in fused siltstone fragment (top right), and vesicles (gas cavities) and elongate feldspar crystals in fine glassy groundmass (bottom left and right).

The off-cuts from the sections, representing duplicates of the clinker and coal ash particles studied under the microscope, were pulverized, and the respective powders analysed by X-ray diffraction (XRD) using a Philips X'pert PW1830 diffractometer system. The percentages of the individual crystalline phases (minerals) in each sample were determined using the Rietveld-based Siroquant software system [14], with XRD data for a poorly crystalline metakaolin component incorporated in each task to evaluate 
the proportion of non-crystalline (amorphous) or glassy components [11]. The results obtained from this approach were checked by separate tests involving the addition of a weighed-in $\mathrm{ZnO}$ spike to some coal ash samples [11], which confirmed that the metakaolin provided a consistent basis for evaluation of the amorphous content. The chemical composition of each powdered sample was also determined by X-ray fluorescence (XRF) spectrometry, based on the sample preparation procedures of Norrish and Chappell [15]. The abundance of the individual crystalline phases as indicated by the XRD analysis, combined with the respective stoichiometric compositions, was used to estimate the overall chemical composition of the crystalline components. Electron microprobe studies, discussed further below, confirm that the use of stoichiometric compositions is appropriate to represent the principal minerals, especially quartz and anorthite, in the bulk gasification ash, heated stone and clinker samples of the present study. The overall composition of the glassy (amorphous) phase in each case was then estimated by subtracting the proportion and inferred composition of the crystalline phases from the bulk ash composition, following procedures described by Ward and French [11]. The mineral matter in the feed coal for the gasifier was also evaluated, to provide information on the sources of the different ash components. A sample made up of $-1 \mathrm{~mm}$ particles of the crushed feed coal was screened on a $0.25 \mathrm{~mm}$ sieve to produce a fine coal $(100 \%<0.25 \mathrm{~mm}$ particles) and a coarse coal fraction $(100 \%>0.25 \mathrm{~mm}$ particles $)$. Each fraction was separated by float-sink techniques at a density of $1.56 \mathrm{~g} / \mathrm{cm}^{3}$ into a lowdensity ("floats") fraction, a "middlings" fraction, and a high-density or "sinks" fraction. The mineral matter in the feed coal, and also the individual size and density fractions, was isolated using low-temperature oxygen-plasma ashing [16], and the resulting LTA residues subjected to quantitative Rietveld-based X-ray diffraction analysis [17].

\section{Results and discussion}

\subsection{Mineral matter in feed coal}

As indicated in Table 1, the feed coal was found to have around 35\% mineral matter (LTA), made up mainly of kaolinite (53\%), quartz and dolomite, with minor proportions of illite, calcite, pyrite, and the phosphate minerals apatite $\left(\mathrm{Ca}_{5} \mathrm{~F}\left(\mathrm{PO}_{4}\right)_{3}\right)$ and gorceixite $\left(\mathrm{BaAl}_{3}\left(\mathrm{PO}_{4}\right)_{2}(\mathrm{OH})_{5} \cdot \mathrm{H}_{2} \mathrm{O}\right)$. A small proportion of bassanite $\left(\mathrm{CaSO}_{4} \cdot 1 / 2 \mathrm{H}_{2} \mathrm{O}\right)$ was also 
present in the LTA sample, probably derived from interaction of organically-associated calcium in the coals with organic sulphur during the low-temperature ashing process.

Such a mineral assemblage is consistent with similar data on the mineral matter in other South African coals [18].

Table 1.

Mineralogy of LTA isolated from feed coal and float-sink fractions (wt\%)

\begin{tabular}{|l|l|l|l|l|l|l|l|}
\hline Sample & $\begin{array}{l}\text { Feed } \\
\text { coal }\end{array}$ & $\begin{array}{l}\text { Coarse } \\
\text { floats }\end{array}$ & $\begin{array}{l}\text { Coarse } \\
\text { middlings }\end{array}$ & $\begin{array}{l}\text { Coarse } \\
\text { sinks }\end{array}$ & $\begin{array}{l}\text { Fine } \\
\text { floats }\end{array}$ & $\begin{array}{l}\text { Fine } \\
\text { middlings }\end{array}$ & $\begin{array}{l}\text { Fine } \\
\text { sinks }\end{array}$ \\
\hline LTA & 34.6 & 15.0 & 35.4 & 55.4 & 14.9 & 37.9 & 53.6 \\
\hline Quartz & 18.2 & 9.3 & 15.9 & 19.8 & 11.1 & 17.3 & 24.7 \\
\hline Kaolinite & 53.3 & 61.0 & 62.7 & 58.8 & 62.8 & 54.4 & 49.0 \\
\hline Illite & 5.6 & 13.8 & 3.3 & 5.9 & 4.8 & 5.3 & 7.3 \\
\hline Calcite & 2.7 & & & & & & \\
\hline Dolomite & 11.2 & 7.8 & 8.5 & 2.8 & 10.2 & 12.9 & 6.5 \\
\hline Pyrite & 2.8 & 1.5 & 0.7 & 5.5 & 0.3 & 1.0 & 4.8 \\
\hline Bassanite & 2.2 & 4.5 & 4.9 & 5.2 & 9.3 & 7.4 & 5.2 \\
\hline Rutile & 1.1 & & 0.4 & 0.8 & 0.3 & & 0.5 \\
\hline Gorceixite & 1.9 & 2.1 & 3.5 & 1.4 & 1.3 & 1.7 & 1.9 \\
\hline Apatite & 1.0 & & & & & & \\
\hline
\end{tabular}

Data on the different size and density fractions, also summarised in Table 1, indicate that the float fractions, with low percentages of LTA, have a mineral assemblage with lesser proportions of quartz and pyrite than the LTA-rich sinks fractions. Dolomite, by contrast, is more abundant in the floats and middlings fractions than in the high-density sinks 
material. Together with the greater abundance of dolomite in the fine fractions than the coarse fractions, this suggests a relatively intimate association of the carbonate minerals with the maceral components. Apart from a greater abundance of illite in the coarse floats material, the clay minerals, the phosphates and the bassanite all appear to be more or less evenly distributed among the different size and density fractions.

\subsection{Chemical composition of bulk gasification ash, heated stone and clinker samples}

Chemical analysis (Table 2) indicates a wide variation in the composition of the individual ash, stone and clinker samples evaluated in the study. The main constituents in all cases are $\mathrm{SiO}_{2}, \mathrm{Al}_{2} \mathrm{O}_{3}, \mathrm{Fe}_{2} \mathrm{O}_{3}, \mathrm{CaO}, \mathrm{MgO}$ and $\mathrm{TiO}_{2}$, with minor proportions $(<1 \%)$ of $\mathrm{Na}_{2} \mathrm{O}, \mathrm{K}_{2} \mathrm{O}, \mathrm{MnO}, \mathrm{P}_{2} \mathrm{O}_{5}$ and $\mathrm{SO}_{3}$ also being present. Measurable concentrations of $\mathrm{BaO}$ and $\mathrm{SrO}$ occur in many of the coal gasification ash samples. The proportions of $\mathrm{MgO}$, $\mathrm{SrO}$ and $\mathrm{BaO}$ can be correlated with the proportion of $\mathrm{CaO}$ (Fig. 3), suggesting on the basis of other studies [19] that they may be associated with the carbonate minerals in the feed coal.

\section{Table 2.}

Chemical composition of coal LTA inferred from XRD, and of coal gasification ash, clinker and heated rock samples determined by XRF analysis (wt\%)

\begin{tabular}{|l|l|l|l|l|l|l|l|}
\hline Oxide & $\begin{array}{l}\text { Coal } \\
\text { LTA }\end{array}$ & $\begin{array}{l}\text { Bulk } \\
\text { gasification ash }\end{array}$ & $\begin{array}{l}\text { Clinker } \\
\mathbf{1}\end{array}$ & Clinker 2 & Clinker 3 & Clinker 4 & Clinker 5 \\
\hline $\mathrm{SiO}_{2}$ & 54.3 & 49.4 & 41 & 48.7 & 49.8 & 60.9 & 49.3 \\
\hline $\mathrm{Al}_{2} \mathrm{O}_{3}$ & 28.2 & 24.4 & 24 & 27.9 & 25.8 & 23.4 & 23.7 \\
\hline $\mathrm{Fe}_{2} \mathrm{O}_{3}$ & 2.21 & 4.06 & 4.39 & 3.26 & 5.71 & 1.16 & 4.93 \\
\hline $\mathrm{CaO}$ & 7.79 & 7.76 & 13.8 & 9.28 & 5.81 & 4.94 & 8.29 \\
\hline $\mathrm{MgO}$ & 2.91 & 2.34 & 4.62 & 3.06 & 2.05 & 1.81 & 3.13 \\
\hline $\mathrm{TiO}_{2}$ & 1.3 & 1.36 & 1.25 & 1.45 & 2.07 & 1.73 & 1.46 \\
\hline $\mathrm{Na}_{2} \mathrm{O}$ & 0 & 0.76 & 0.61 & 0.68 & 0.49 & 0.45 & 0.56 \\
\hline $\mathrm{K}_{2} \mathrm{O}$ & 0.6 & 0.88 & 0.67 & 0.72 & 1.01 & 0.54 & 0.69 \\
\hline $\mathrm{MnO}$ & & 0.05 & 0.075 & 0.06 & 0.05 & 0.08 & 0.06 \\
\hline
\end{tabular}


openUP (May 2008)

\begin{tabular}{|c|c|c|c|c|c|c|c|}
\hline Oxide & $\begin{array}{l}\text { Coal } \\
\text { LTA }\end{array}$ & $\begin{array}{l}\text { Bulk } \\
\text { gasification ash }\end{array}$ & $\begin{array}{l}\text { Clinker } \\
1\end{array}$ & Clinker 2 & Clinker 3 & Clinker 4 & Clinker 5 \\
\hline $\mathrm{P}_{2} \mathrm{O}_{5}$ & 1.25 & 0.72 & 0.896 & 0.89 & 0.97 & 0.39 & 0.56 \\
\hline $\mathrm{SO}_{3}$ & 1.44 & 0.25 & 0.221 & 0.102 & 0.03 & 0.09 & 0.676 \\
\hline $\mathrm{SrO}$ & & 0.38 & 0.498 & 0.44 & 0.51 & 0.2 & 0.323 \\
\hline $\mathrm{BaO}$ & & 0.24 & 0.293 & 0.29 & 0.4 & 0.16 & 0.242 \\
\hline $\mathrm{ZrO}_{2}$ & & 0.05 & 0.048 & 0.06 & 0.06 & 0.05 & 0.048 \\
\hline LOI & & 8.2 & 8.52 & 3.1 & 4.82 & 4.6 & 7.27 \\
\hline \multirow[t]{2}{*}{ Total } & 100 & 101 & 101 & 100 & 99.7 & 101 & 101 \\
\hline & Clinker 6 & Clinker 7 & Clinker 8 & $\begin{array}{l}\text { Heated } \\
\text { stone } 1\end{array}$ & $\begin{array}{l}\text { Heated } \\
\text { stone } 2\end{array}$ & $\begin{array}{l}\text { Heated } \\
\text { stone } 3\end{array}$ & $\begin{array}{l}\text { Heated } \\
\text { stone } 4\end{array}$ \\
\hline $\mathrm{SiO}_{2}$ & 61 & 56.5 & 43.2 & 76.9 & 80.01 & 52.5 & 57.4 \\
\hline $\mathrm{Al}_{2} \mathrm{O}_{3}$ & 28.8 & 26.5 & 27.7 & 9.89 & 10.7 & 25.3 & 25.8 \\
\hline $\mathrm{Fe}_{2} \mathrm{O}_{3}$ & 1.2 & 2.9 & 3.9 & 1.53 & 1.37 & 9.34 & 1.07 \\
\hline $\mathrm{CaO}$ & 0.87 & 5.31 & 12.6 & 1.33 & 0.63 & 0.46 & 0.39 \\
\hline $\mathrm{MgO}$ & 0.65 & 1.9 & 4.11 & 0.32 & 0.3 & 0.43 & 0.4 \\
\hline $\mathrm{TiO}_{2}$ & 0.67 & 1.2 & 1.51 & 1.24 & 1.1 & 0.96 & 1.57 \\
\hline $\mathrm{Na}_{2} \mathrm{O}$ & 0.34 & 0.73 & 0.73 & 0.4 & 0.32 & 0.29 & 0.29 \\
\hline $\mathrm{K}_{2} \mathrm{O}$ & 1.25 & 1.32 & 0.68 & 2.19 & 2.44 & 1.72 & 0.9 \\
\hline $\mathrm{MnO}$ & 0.01 & 0.04 & 0.08 & 0.017 & 0.01 & 0.011 & 0.004 \\
\hline $\mathrm{P}_{2} \mathrm{O}_{5}$ & 0.09 & 0.47 & 1.06 & 0.062 & 0.066 & 0.07 & 0.196 \\
\hline $\mathrm{SO}_{3}$ & 0.001 & 0.054 & 0.04 & 0.187 & 0.227 & 0.29 & 0.21 \\
\hline $\mathrm{SrO}$ & 0.034 & 0.24 & 0.53 & 0.029 & 0.024 & 0.018 & 0.111 \\
\hline $\mathrm{BaO}$ & 0.101 & 0.18 & 0.33 & 0.083 & 0.077 & 0.081 & 0.155 \\
\hline $\mathrm{ZrO}_{2}$ & 0.018 & 0.04 & 0.04 & 0.252 & 0.213 & 0.023 & 0.053 \\
\hline LOI & 4.61 & 1.93 & 4.47 & 5.08 & 1.6 & 8.45 & 11.32 \\
\hline Total & 99.7 & 99.1 & 101 & 99.7 & 99.2 & 99.9 & 99.9 \\
\hline
\end{tabular}


Note: $\mathrm{LOI}=\operatorname{Loss}$ on ignition at $1050{ }^{\circ} \mathrm{C}$.

Samples:

Coal LTA $=$ inferred chemistry of coal ash based on mineralogy of LTA (Table 1).

Clinker $1=$ a small heterogeneous clinker with black and white colours taken from the gasification ash exiting the gasifier.

Clinker 2 = a medium heterogeneous clinker with white and black colours taken from the gasification ash exiting the gasifier.

Clinker $3=$ a large heterogeneous clinker with black colour taken from the gasification ash exiting the gasifier.

Clinker 4 = a large heterogeneous clinker with white colour taken from the gasification ash exiting the gasifier.

Clinker $5=$ a largest heterogeneous clinker with black colour taken from the gasification ash exiting the gasifier.

Clinker $6=$ a largest heterogeneous clinker with white colour taken from the gasification ash exiting the gasifier.

Clinker 7 = one lump of clinker sample taken from the bottom of the ash-bed area during turnout sampling.

Clinker $8=$ one lump of clinker sample taken from the gasification zone area during the turnout sampling.

Clinker $9=$ a large heterogeneous clinker with white and black colour taken from the gasification ash exiting the gasifier (Table 6 and Table 7).

Clinker $10=$ a largest heterogeneous clinker with white and black colour taken from the gasification ash exiting the gasifier (Table 6 and Table 7).

Heated stone 1 = one lump of partially burnt carbonaceous shale taken from the gasification ash exiting the gasifier.

Heated stone 2 = one white lump of partially burnt carbonaceous shale taken from the gasification ash exiting the gasifier.

Heated stone $3=$ one lump of partially burnt carbonaceous siltstone taken from the bottom of the ash-bed during turnout sampling. 
Heated stone 4 = one lump of partially burnt carbonaceous sandstone taken from the gasification zone during turnout sampling.
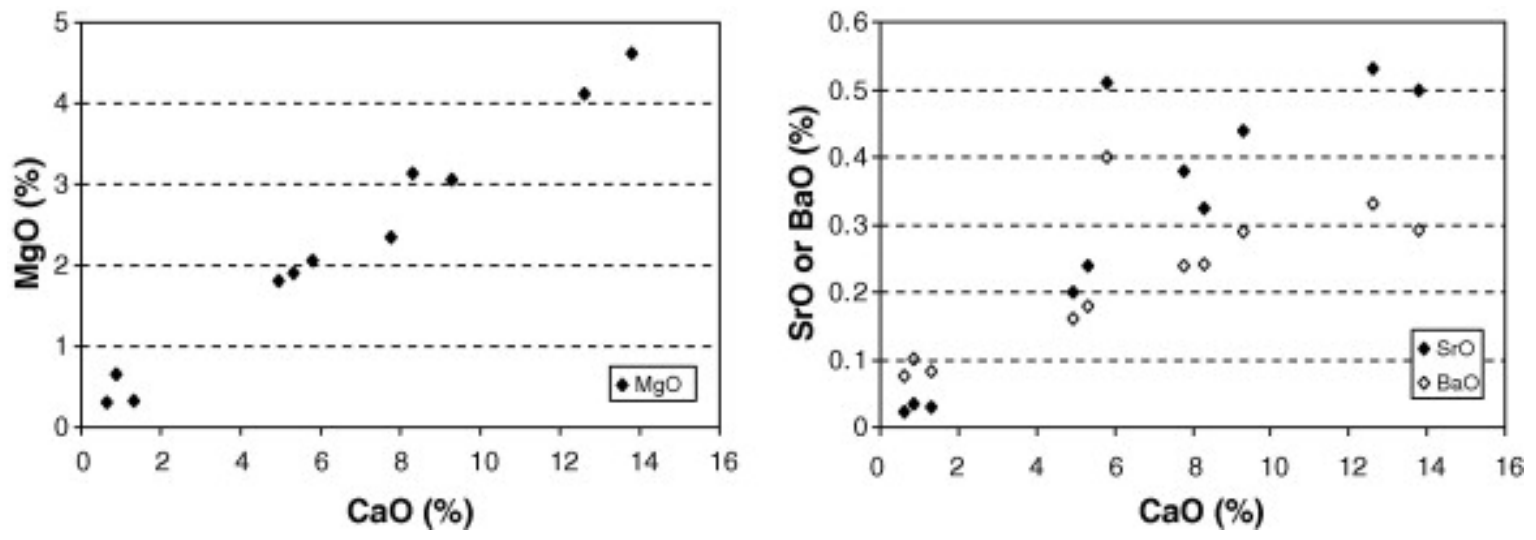

Fig. 3. Correlation of $\mathrm{MgO}$ (left), $\mathrm{SrO}$ and $\mathrm{BaO}$ (right) with $\mathrm{CaO}$ in ash samples studied. The composition of the bulk ash from the gasifier is similar to the ash chemistry expected from the mineral matter of the feed coal, calculated from the percentages and stoichiometric compositions of the minerals listed in Table 1 . The abundance of bassanite has given rise to a greater percentage of (inferred) $\mathrm{SO}_{3}$ in the LTA than that observed in the bulk gasification ash. The difference may reflect the higher temperatures associated with the gasification process, which would be expected to break down any calcium sulphates and convert more of the sulphur to volatile form.

As discussed more fully below, the wide variations in chemical composition of the clinker samples are also reflected in the mineralogical composition of the materials, as well as the nature of the glasses occurring in the respective sample types. Each sample typically represents an individual fragment of either coal or carbonaceous shale (stone) that occurred within the coarse feed coal, after being been subjected to the high temperatures and pressures of the gasification process. For example, the results given in Table 2 indicate that the samples of partially burnt carbonaceous shale (heated stones 1 and 2) have higher concentrations of $\mathrm{SiO}_{2}$ and $\mathrm{K}_{2} \mathrm{O}$ and lower concentrations of $\mathrm{Al}_{2} \mathrm{O}_{3}$ than the clinker samples (1, 2, etc.) analysed in the study. Based on data from a range of other South African coals and associated rocks [18], this suggests derivation from a material rich in quartz, feldspar and/or illitic clay minerals, rather than the kaolinite-rich clays and associated carbonate minerals (Table 1) associated with the coals themselves. 
In most cases the white clinker particles (e.g. 4,6) contain higher proportions of $\mathrm{SiO}_{2}$ than the corresponding black or grey clinker particles (e.g. 3 and 5), and lower proportions of $\mathrm{Fe}_{2} \mathrm{O}_{3}, \mathrm{CaO}, \mathrm{SrO}$ and $\mathrm{BaO}$ (Table 2). The latter oxides, especially $\mathrm{CaO}$ and $\mathrm{Fe}_{2} \mathrm{O}_{3}$ (which reacts as $\mathrm{FeO}$ ), are generally thought to be associated with sintering of coal ash materials. Briggs and Lindsay [8] indicate that clay minerals may react with partiallyoxidized pyrite $\left(\mathrm{Fe}_{7} \mathrm{~S}_{8}\right)$ and $\mathrm{CaO}$ from calcite at $750-760{ }^{\circ} \mathrm{C}$ to form silicate glass. Bryers [3], Ward [20] and Raask [21] also indicate that $\mathrm{CaO}$ interacts with reactive aluminium silicates such as metakaolin at high temperatures $\left(1000-1200^{\circ} \mathrm{C}\right)$ to form gehlenite $\left(\mathrm{Ca}_{2} \mathrm{Al}_{2} \mathrm{SiO}_{7}\right)$ and anorthite $\left(\mathrm{CaAl}_{2} \mathrm{Si}_{2} \mathrm{O}_{8}\right)$, which in turn fuse at about $1400-1500{ }^{\circ} \mathrm{C}$. The partly burnt rock samples (heated stones 3 and 4 ) also have lower proportions of $\mathrm{CaO}$ than their counterpart clinker samples.

\subsection{Mineralogy of bulk gasification ash and clinker samples}

XRD analysis (Table 3) indicates that the bulk gasification ash sample contains around $10 \%$ quartz, together with $18 \%$ mullite $\left(\mathrm{Al}_{6} \mathrm{Si}_{2} \mathrm{O}_{13}\right), 13 \%$ anorthite $\left(\mathrm{CaAl}_{2} \mathrm{Si}_{2} \mathrm{O}_{8}\right)$ and around $50 \%$ amorphous glass. Small proportions of cristobalite $\left(\mathrm{SiO}_{2}\right)$ and diopside $\left(\mathrm{CaMgSi}_{2} \mathrm{O}_{6}\right)$ are also present. The cristobalite was probably formed from the amorphous decomposition products of the clay minerals, kaolinite and illite. The remaining available amorphous silica may have reacted with high temperature transformation products $(\mathrm{CaO}$ and $\mathrm{MgO}$ ) of carbonates (calcite and dolomite) to form diopside. The different clinker particles picked from the gasification ash (clinkers 1, 2, 7, 8, 9 and 10) contain similar phases, including glass, although the proportions vary from fragment to fragment depending on factors such as the fragment's original composition and the temperature reached by the fragment in the ash bed. 
Table 3.

Mineralogy of coal gasification ash, clinker and heated rock samples by XRD and Siroquant $(w t \%)$

\begin{tabular}{|c|c|c|c|c|c|c|c|}
\hline Mineral & $\begin{array}{l}\text { Bulk coal } \\
\text { gasification ash }\end{array}$ & Clinker 1 & Clinker 2 & Clinker 3 & Clinker 4 & Clinker 5 & Clinker 6 \\
\hline Quartz & 10.7 & 3.9 & 0.2 & 3.7 & 10.6 & 5.5 & 14.6 \\
\hline Anorthite & 13.1 & 27.0 & 51.6 & 19.5 & 10.4 & 38.8 & 2.3 \\
\hline Mullite & 17.7 & 5.7 & 9.5 & 13.9 & 22.1 & 10.7 & 29.7 \\
\hline Cristobalite & 1.8 & & 1.7 & 5.5 & 10.2 & 4.2 & \\
\hline Diopside & 0.7 & 12.1 & & 1.9 & 0.9 & & \\
\hline \multicolumn{8}{|l|}{ Illite } \\
\hline \multicolumn{8}{|l|}{ Anatase } \\
\hline \multicolumn{8}{|l|}{ Rutile } \\
\hline \multicolumn{8}{|l|}{ Calcite } \\
\hline \multicolumn{8}{|l|}{ Dolomite } \\
\hline \multicolumn{8}{|l|}{ Pyrrhotite } \\
\hline \multirow[t]{2}{*}{ Amorphous $^{\mathbf{a}}$} & 56.0 & 51.3 & 37.0 & 55.7 & 45.8 & 40.8 & 53.4 \\
\hline & Clinker 7 & Clinker 8 & $\begin{array}{l}\text { Heated } \\
\text { stone } 1\end{array}$ & $\begin{array}{l}\text { Heated } \\
\text { stone } 2\end{array}$ & $\begin{array}{l}\text { Heated } \\
\text { stone } 3\end{array}$ & $\begin{array}{l}\text { Heated } \\
\text { stone } 4\end{array}$ & \\
\hline Quartz & 12.9 & 1.5 & 61.8 & 50.8 & 21.3 & 24.9 & \\
\hline Anorthite & 8.4 & 62.3 & 3.2 & 2.3 & & & \\
\hline Mullite & 17.0 & 5.8 & 14.8 & 7.7 & 19.7 & & \\
\hline Cristobalite & & 1.0 & & & & & \\
\hline Diopside & & 12.1 & & & & & \\
\hline Illite & & & & & 7.9 & & \\
\hline Anatase & 0.1 & & & & 0.6 & 1.1 & \\
\hline Rutile & & & & & & 0.8 & \\
\hline \multicolumn{8}{|l|}{ Calcite } \\
\hline Dolomite & & & & & & 0.3 & \\
\hline Pyrrhotite & & & & & 6.4 & & \\
\hline Amorphous $^{\mathbf{a}}$ & 61.6 & 17.3 & 20.1 & 39.2 & 44.2 & 73.0 & \\
\hline
\end{tabular}


${ }^{a}$ Includes both non-crystalline glass and any unburnt carbon (char) components. Samples of the partially burned carbonaceous shale taken from the gasification ash (heated stones 1 and 2), as well as partly burned siltstone and sandstone (heated stones 3 and 4), have higher proportions of quartz, but little if any anorthite, cristobalite or diopside. Table 3 indicates, for example, that heated stone 1 contains $7.9 \%$ illite, $6.4 \%$ pyrrhotite and traces of anatase and/or rutile $\left(\mathrm{TiO}_{2}\right)$, all of which presumably represent unaltered or partly altered remnants of the original sedimentary material. The presence of remnant illite particles in the heated stone samples is attributed to a combination of factors and processes, including incomplete thermal decomposition of the rock fragments entering the gasifier with the coal, the typical wide range of particle sizes (leading to incomplete fusion of the larger particles), and variations in operating procedures. The presence of pyrrhotite $(\mathrm{FeS})$ in heated stone 3 probably represents an alteration product of pyrite in the original rock, developed by heating under reducing conditions.

Dynamic high temperature XRD studies on other materials [22] suggest that mullite and cristobalite form from the residues of clay minerals in the parent coal, especially the kaolinite, by solid-state reactions that commence at around $1000{ }^{\circ} \mathrm{C}$. Solid-state reactions in calcium-rich mineral matter produce anorthite at similar temperatures, with quartz and/or clay mineral residues being incorporated into the anorthite as part of the process. When tested at progressively higher temperatures the anorthite begins to react with the melt at around $1200{ }^{\circ} \mathrm{C}$, and the mullite and cristobalite in Ca-poor ashes begin to react with the melt at around $1400{ }^{\circ} \mathrm{C}$. Cooling of the molten material, especially the slow cooling associated with the gasifier bed may also be expected to produce crystals of anorthite, as well as the pyroxene mineral diopside, in a manner analogous to the crystallisation of magmas in igneous rock formation.

\subsection{Interpretation of glass composition from XRD and chemical data}

Table 4 and Table 5 provide data on the inferred chemical composition of the crystalline minerals and the glass phases in the ash, clinker and heated rock (stone) samples, estimated from the XRD and whole-sample chemical data (Table 2 and Table 3) following the methodology described by Ward and French [11]. As might be expected from the nature of the materials, a wide range of compositions is implied by these results, 
especially for the glassy phases. For some samples, such as clinker 1 and bulk gasification ash, the crystalline and glassy components appear to have similar overall compositions, at least with respect to the major oxides $\left(\mathrm{SiO}_{2}, \mathrm{Al}_{2} \mathrm{O}_{3}\right.$ and $\left.\mathrm{CaO}\right)$. For most others, however, such as the bulk gasification ash, heated stones $1-2$ and clinkers $2-6$, the glass fraction appears to have a higher proportion of $\mathrm{SiO}_{2}$ and a lesser proportion of $\mathrm{Al}_{2} \mathrm{O}_{3}$. The partitioning of $\mathrm{CaO}$ within this group varies, although most samples appear to have similar to higher proportions of $\mathrm{CaO}$ in the crystalline phases compared to the glassy components.

Table 4.

Inferred composition of mineral and glass fractions for gasification ash and clinker samples (wt $\%)$

\begin{tabular}{|l|l|l|l|l|l|l|}
\hline Sample & \multicolumn{2}{|l|}{ Bulk gasification ash } & \multicolumn{2}{l|}{ Clinker 1 } & \multicolumn{2}{l|}{ Clinker 2 } \\
\hline & Minerals & Glass & Minerals & Glass & Minerals & Glass \\
\hline Fraction & 44.6 & 55.4 & 48.7 & 51.3 & 63 & 37 \\
\hline $\mathrm{SiO}_{2}$ & 53.43 & 53.98 & 49.66 & 40.25 & 43.55 & 62.89 \\
\hline $\mathrm{TiO}_{2}$ & 0.67 & 2.13 & & 2.66 & & 4.08 \\
\hline $\mathrm{Al}_{2} \mathrm{O}_{3}$ & 38.87 & 16.62 & 28.14 & 24.44 & 39.99 & 10.43 \\
\hline $\mathrm{Fe}_{2} \mathrm{O}_{3}$ & & 7.97 & & 9.36 & & 9.17 \\
\hline $\mathrm{MgO}$ & & 4.59 & 4.62 & 5.46 & & 8.61 \\
\hline $\mathrm{CaO}^{2}$ & 6.5 & 10.01 & 17.58 & 12.73 & 16.46 & -1.92 \\
\hline $\mathrm{Na}_{2} \mathrm{O}$ & & 1.49 & & 1.3 & & 1.91 \\
\hline $\mathrm{K}_{2} \mathrm{O}$ & & 1.73 & & 1.43 & & 2.03 \\
\hline $\mathrm{P}_{2} \mathrm{O}_{5}$ & & 1.41 & & 1.91 & & 2.5 \\
\hline $\mathrm{SO}_{3}$ & 0.53 & 0.07 & & 0.47 & & 0.29 \\
\hline & & & & & & \\
\hline $\mathrm{Total}$ & 100 & 100 & 100 & 100 & 100 & 100 \\
\hline & & & & & & \\
\hline
\end{tabular}




\begin{tabular}{|c|c|c|c|c|c|c|}
\hline & \multicolumn{2}{|l|}{ Clinker 3} & \multicolumn{2}{|l|}{ Clinker 4} & \multicolumn{2}{|l|}{ Clinker 5} \\
\hline & Minerals & Glass & Minerals & Glass & Minerals & Glass \\
\hline Fraction & 44.5 & 55.5 & 54.2 & 45.8 & 59.2 & 40.8 \\
\hline $\mathrm{SiO}_{2}$ & 51.26 & 54.62 & 59.3 & 69.19 & 50.52 & 56.22 \\
\hline $\mathrm{TiO}_{2}$ & & 3.98 & & 3.96 & & 3.84 \\
\hline $\mathrm{Al}_{2} \mathrm{O}_{3}$ & 38.03 & 19.1 & 36.11 & 10.82 & 36.31 & 9.58 \\
\hline $\mathrm{Fe}_{2} \mathrm{O}_{3}$ & & 10.98 & & 2.65 & & 12.95 \\
\hline $\mathrm{MgO}$ & 0.79 & 3.3 & 0.31 & 3.78 & & 8.22 \\
\hline $\mathrm{CaO}$ & 9.91 & 3.22 & 4.29 & 6.23 & 13.17 & 2.66 \\
\hline $\mathrm{Na}_{2} \mathrm{O}$ & & 0.94 & & 1.03 & & 1.47 \\
\hline $\mathrm{K}_{2} \mathrm{O}$ & & 1.94 & & 1.24 & & 1.81 \\
\hline $\mathrm{P}_{2} \mathrm{O}_{5}$ & & 1.86 & & 0.89 & & 1.47 \\
\hline $\mathrm{SO}_{3}$ & & 0.06 & & 0.21 & & 1.78 \\
\hline \multirow[t]{3}{*}{ Total } & 100 & 100 & 100 & 100 & 100 & 100 \\
\hline & \multicolumn{2}{|l|}{ Clinker 6} & \multicolumn{2}{|l|}{ Clinker 7} & \multicolumn{2}{|l|}{ Clinker 8} \\
\hline & Minerals & Glass & Minerals & Glass & Minerals & Glass \\
\hline Fraction & 46.6 & 53.4 & 38.4 & 61.6 & 82.7 & 17.3 \\
\hline $\mathrm{SiO}_{2}$ & 51.49 & 75.47 & 55.77 & 59.91 & 46.49 & 39.14 \\
\hline $\mathrm{TiO}_{2}$ & & 1.32 & 0.26 & 1.85 & & 9.14 \\
\hline $\mathrm{Al}_{2} \mathrm{O}_{3}$ & 47.52 & 15.38 & 39.57 & 19.73 & 31.85 & 15.33 \\
\hline $\mathrm{Fe}_{2} \mathrm{O}_{3}$ & & 2.37 & & 4.86 & & 23.6 \\
\hline $\mathrm{MgO}$ & & 1.28 & & 3.18 & 2.72 & 11.86 \\
\hline $\mathrm{CaO}$ & 0.99 & 0.85 & 4.4 & 6.16 & 18.93 & -14.26 \\
\hline $\mathrm{Na}_{2} \mathrm{O}$ & & 0.67 & & 1.22 & & 4.42 \\
\hline $\mathrm{K}_{2} \mathrm{O}$ & & 2.47 & & 2.21 & & 4.11 \\
\hline $\mathrm{P}_{2} \mathrm{O}_{5}$ & & 0.18 & & 0.79 & & 6.41 \\
\hline $\mathrm{SO}_{3}$ & & & & 0.09 & & 0.24 \\
\hline Total & 100 & 100 & 100 & 100 & 100 & 100 \\
\hline
\end{tabular}


Table 5.

Inferred composition of mineral and glass fractions for heated stone samples (wt $\%)$

\begin{tabular}{|c|c|c|c|c|c|c|c|c|}
\hline \multirow[t]{2}{*}{ Sample } & \multicolumn{2}{|c|}{ Heated stone 1} & \multicolumn{2}{|c|}{ Heated stone 2} & \multicolumn{2}{|c|}{ Heated stone 3} & \multicolumn{2}{|c|}{ Heated stone 4} \\
\hline & Minerals & Glass & Minerals & Glass & Minerals & Glass & Minerals & Glass \\
\hline Fraction & 79.8 & 20.2 & 60.8 & 39.2 & 55.8 & 44.2 & 27 & 73 \\
\hline $\mathrm{SiO}_{2}$ & 84.45 & 71.16 & 88.8 & 72.34 & 55.2 & 60.3 & 92.2 & 55 \\
\hline $\mathrm{TiO}_{2}$ & & 6.53 & & 2.89 & 1.1 & 1 & 6.7 & 0 \\
\hline $\mathrm{Al}_{2} \mathrm{O}_{3}$ & 14.74 & -6.19 & 10.44 & 11.9 & 30.5 & 24.2 & & 40.1 \\
\hline $\mathrm{Fe}_{2} \mathrm{O}_{3}$ & & 8.05 & & 3.6 & 5.3 & 16.5 & & 1.7 \\
\hline $\mathrm{MgO}$ & & 1.68 & & 0.79 & & 1.1 & 0.2 & 0.5 \\
\hline $\mathrm{CaO}$ & 0.81 & 3.82 & 0.76 & 0.47 & & 1.1 & 0.3 & 0.5 \\
\hline $\mathrm{Na}_{2} \mathrm{O}$ & & 2.11 & & 0.84 & & 0.7 & & 0.5 \\
\hline $\mathrm{K}_{2} \mathrm{O}$ & & 11.53 & & 6.41 & 1.3 & 2.6 & & 1.4 \\
\hline $\mathrm{P}_{2} \mathrm{O}_{5}$ & & 0.33 & & 0.17 & & 0.2 & & 0.3 \\
\hline $\mathrm{H}_{2} \mathrm{O}$ & & & & & 0.7 & -0.8 & & \\
\hline $\mathrm{CO}_{2}$ & & & & & & & 0.5 & -0.2 \\
\hline S & & & & & 6 & -7.6 & & \\
\hline $\mathrm{SO}_{3}$ & & 0.98 & & 0.6 & & 0.7 & & 0.3 \\
\hline Total & 100 & 100 & 100 & 100 & 100 & 100 & 100 & 100 \\
\hline
\end{tabular}

Negative percentage values are noted in some instances. These may reflect overestimation of the abundance of particular crystalline phases (e.g. anorthite), or possibly under-estimation of glass content, by the XRD technique.

As pointed out by Ward and French [11], the material identified as glass by the XRD technique is not necessarily of uniform composition within the individual ash samples. It may also include particles of crystalline components that are too low in abundance or too 
small in particle size to be identified separately by X-ray diffraction methods. Some of the crystalline phases, such as mullite, may also have different chemical compositions to the stoichiometric data used in interpreting the XRD results. Although the electron microprobe study has identified some discrete solid particles made up mainly of $\mathrm{Fe}$ and $\mathrm{Ti}$ (see below), these make up only a small proportion of the relevant ash or slag samples. None of the crystalline phases identified in the samples by XRD techniques would normally be expected to contain iron, titanium, magnesium or sodium, and these elements are therefore interpreted from the XRD and bulk chemical data to occur only in the glassy phases of the samples studied.

\subsection{Determination of glass and mineral compositions by electron microprobe analysis}

Electron microprobe analysis was used to determine the chemical composition of the principal crystalline and glassy phases in polished sections and polished thin sections of selected lump clinker samples. Images illustrating the textures in a typical sample, showing the modes of occurrence of quartz, feldspar and glassy phases, are provided in Fig. 4. The chemical composition of the quartz, feldspar and aluminosilicate glass for a wider range of samples, based on the microprobe study, is given in Table 6 . 

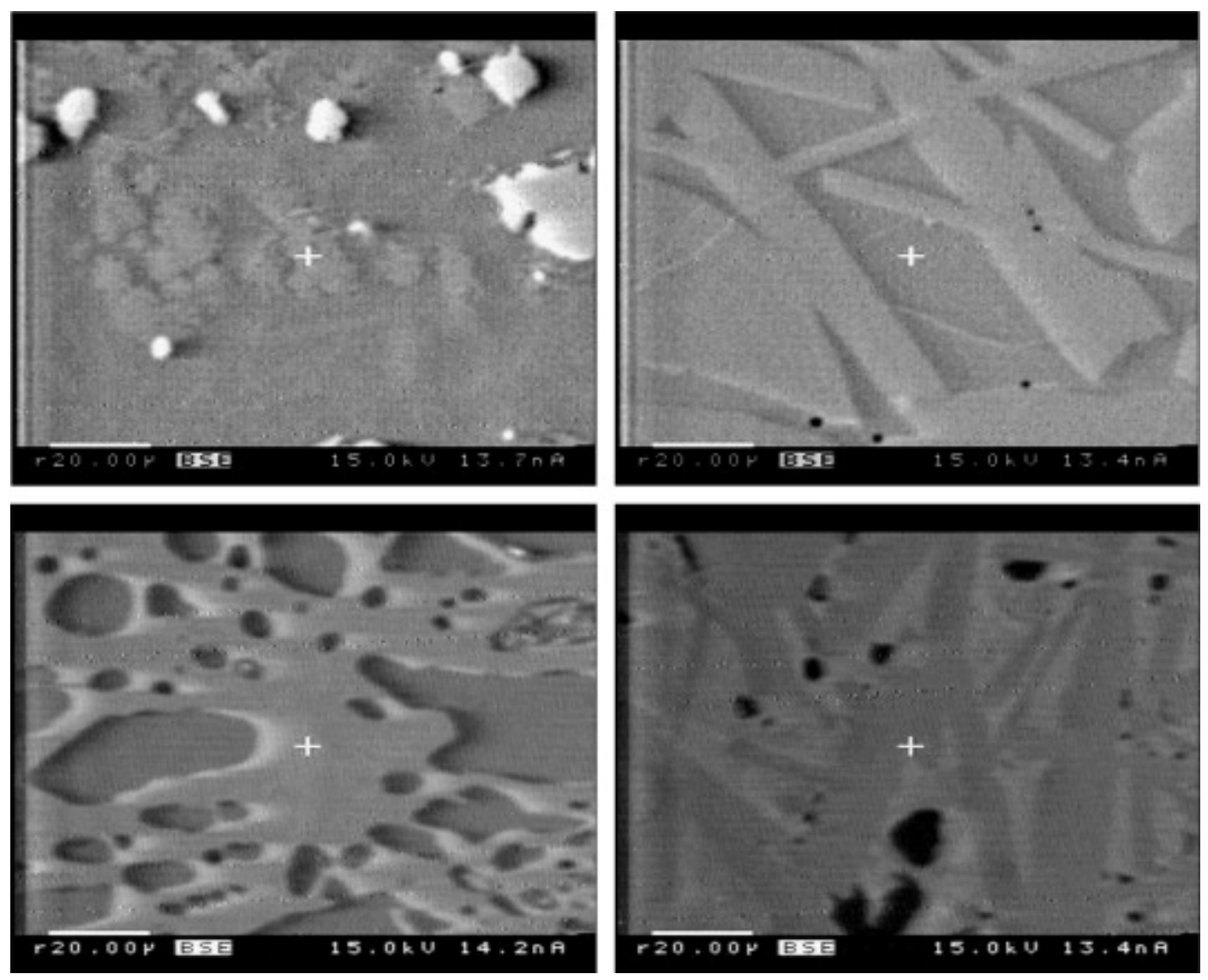

Fig. 4. Electron microprobe images of slag samples (back-scattered electron mode) in Clinker 2. (Top left) Quartz particles (mid grey) set in glassy matrix; (top right) elongate anorthite crystals (light grey) with interstitial glass; (bottom left) homogeneous vesicular glass; (bottom right) anorthite crystals (mid grey) with vesicles (black) in interstitial light grey glass. Scale bar in each case represents $20 \mu \mathrm{m}$. 
openUP (May 2008)

Table 6.

Composition of main mineral fragments and glass matrix in coal gasification ash samples (wt $\%$ ), as determined by electron microprobe analysis

\begin{tabular}{|c|c|c|c|c|c|c|c|c|c|c|c|c|c|}
\hline & Pts & $\mathrm{SiO}_{2}$ & $\mathrm{TiO}_{2}$ & $\mathbf{A l}_{2} \mathbf{O}_{3}$ & $\mathrm{Fe}_{2} \mathrm{O}_{3}$ & MgO & MnO & $\mathrm{CaO}$ & $\mathrm{Na}_{2} \mathrm{O}$ & $\mathrm{K}_{2} \mathrm{O}$ & $\mathbf{P}_{2} \mathbf{O}_{5}$ & $\mathrm{SO}_{3}$ & Total \\
\hline \multicolumn{14}{|l|}{ Quartz } \\
\hline $\begin{array}{l}\text { Bulk } \\
\text { gasifica- } \\
\text { tion ash }\end{array}$ & 7 & 98.98 & 0.01 & 0.29 & 0.20 & 0.01 & 0.01 & 0.01 & 0.02 & 0.15 & 0.01 & 0.02 & 99.71 \\
\hline Clinker 1 & 2 & 100.43 & 0.02 & 0.04 & 0.01 & 0.00 & 0.01 & 0.00 & 0.00 & 0.00 & 0.02 & 0.01 & 100.53 \\
\hline Clinker 2 & 4 & 99.73 & 0.05 & 0.07 & 0.02 & 0.00 & 0.01 & 0.01 & 0.01 & 0.01 & 0.01 & 0.01 & 99.93 \\
\hline Clinker 7 & 8 & 98.39 & 0.09 & 0.14 & 0.03 & 0.01 & 0.02 & 0.01 & 0.01 & 0.01 & 0.02 & 0.02 & 98.75 \\
\hline Clinker 9 & 5 & 94.37 & 0.63 & 3.19 & 0.19 & 0.09 & 0.00 & 0.20 & 0.06 & 0.08 & 0.11 & 0.01 & 98.93 \\
\hline Clinker 10 & 3 & 99.20 & 0.02 & 0.04 & 0.04 & 0.00 & 0.01 & 0.02 & 0.00 & 0.01 & 0.04 & 0.01 & 99.38 \\
\hline $\begin{array}{l}\text { Heated } \\
\text { stone } 3\end{array}$ & 4 & 100.16 & 0.02 & 0.02 & 0.11 & 0.00 & 0.01 & 0.02 & 0.01 & 0.02 & 0.00 & 0.01 & 100.38 \\
\hline \multicolumn{14}{|l|}{ Feldspar } \\
\hline \multicolumn{14}{|l|}{ K-feldspar } \\
\hline $\begin{array}{l}\text { Bulk } \\
\text { gasifica- } \\
\text { tion ash }\end{array}$ & 1 & 63.73 & 0.04 & 18.41 & 0.11 & 0.01 & 0.00 & 0.00 & 0.41 & 16.13 & 0.00 & 0.01 & 98.86 \\
\hline \multicolumn{14}{|l|}{ Anorthite } \\
\hline $\begin{array}{l}\text { Bulk } \\
\text { gasifica- } \\
\text { tion ash }\end{array}$ & 1 & 42.42 & 0.09 & 33.87 & 0.10 & 0.12 & 0.03 & 20.60 & 0.02 & 0.04 & 0.13 & 0.09 & 97.51 \\
\hline Clinker 1 & 7 & 43.74 & 0.16 & 34.40 & 0.38 & 0.38 & 0.03 & 18.48 & 0.36 & 0.08 & 0.10 & 0.01 & 98.12 \\
\hline Clinker 2 & 7 & 44.22 & 0.11 & 34.41 & 0.37 & 0.25 & 0.01 & 18.20 & 0.54 & 0.13 & 0.07 & 0.02 & 98.32 \\
\hline Clinker 7 & 4 & 43.17 & 1.28 & 27.84 & 2.94 & 4.16 & 0.06 & 16.50 & 0.47 & 0.44 & 0.79 & 0.09 & 97.74 \\
\hline Clinker 8 & 7 & 44.56 & 0.29 & 32.27 & 1.22 & 0.99 & 0.01 & 17.81 & 0.76 & 0.29 & 0.23 & 0.04 & 98.46 \\
\hline Clinker 9 & 30 & 45.19 & 0.36 & 31.32 & 1.03 & 1.17 & 0.02 & 16.73 & 0.76 & 0.25 & 0.25 & 0.04 & 97.12 \\
\hline Clinker 10 & 7 & 44.37 & 0.14 & 34.13 & 0.40 & 0.25 & 0.02 & 17.85 & 0.49 & 0.14 & 0.09 & 0.02 & 97.91 \\
\hline
\end{tabular}




\begin{tabular}{|l|l|l|l|l|l|l|l|l|l|l|l|l|l|}
\hline \multicolumn{2}{|l|}{ Si-Al glass } \\
\hline $\begin{array}{l}\text { Bulk } \\
\text { gasifica- } \\
\text { tion ash }\end{array}$ & 14 & 58.37 & 0.42 & 20.90 & 9.41 & 0.43 & 0.02 & 4.80 & 0.16 & 2.86 & 0.03 & 0.16 & 97.55 \\
\hline Clinker 1 & 20 & 44.60 & 2.75 & 14.21 & 4.22 & 13.02 & 0.26 & 13.09 & 0.43 & 1.72 & 1.48 & 0.12 & 95.89 \\
\hline Clinker 2 & 20 & 47.92 & 1.46 & 33.45 & 3.97 & 3.87 & 0.04 & 3.77 & 0.38 & 1.45 & 1.49 & 0.04 & 97.85 \\
\hline Clinker 7 & 20 & 70.18 & 2.94 & 21.01 & 0.82 & 0.47 & 0.02 & 0.47 & 0.28 & 1.30 & 0.04 & 0.02 & 97.55 \\
\hline Clinker 8 & 35 & 22.23 & 2.37 & 33.73 & 16.88 & 18.08 & 0.14 & 4.86 & 0.13 & 0.09 & 0.55 & 0.02 & 99.10 \\
\hline Clinker 9 & 8 & 58.45 & 2.20 & 21.72 & 1.39 & 2.48 & 0.03 & 4.07 & 0.23 & 0.64 & 0.52 & 0.07 & 91.80 \\
\hline Clinker 10 & 16 & 56.56 & 1.13 & 28.70 & 2.61 & 1.43 & 0.05 & 2.77 & 0.39 & 1.61 & 0.49 & 0.11 & 95.84 \\
\hline $\begin{array}{l}\text { Heated } \\
\text { stone 3 }\end{array}$ & 54 & 54.83 & 0.24 & 15.80 & 1.74 & 2.11 & 0.01 & 3.12 & 3.46 & 0.98 & 0.06 & 1.38 & 83.72 \\
\hline
\end{tabular}

\subsubsection{Quartz and feldspar crystals}

The quartz grains in the bulk gasification ash, heated stone and clinker samples are typically irregular, broadly equidimensional particles, and probably represent unreacted fragments inherited from the coal and non-coal (sandstone, siltstone, carbonaceous shale) components in the feedstock to the gasification process. Fig. 4, top left, for example, shows a series of silt-sized quartz grains each around $10 \mu \mathrm{m}$ in size. Table 6 indicates that the quartz particles are essentially pure, with usually more than $98 \% \mathrm{SiO}_{2}$. Traces of $\mathrm{Al}_{2} \mathrm{O}_{3}, \mathrm{Fe}_{2} \mathrm{O}_{3}, \mathrm{CaO}$ and $\mathrm{TiO}_{2}$ are also present in some cases.

The data indicate that the quartz grains, which might otherwise react to form feldspar or glass, especially above the quartz melting point of $1710^{\circ} \mathrm{C}$, can also persist as essentially unreacted particles throughout the different stages of the gasification process. Benson [23] indicates that quartz in lignite samples changes to $\beta_{2}$-tridymite on heating (870$1470{ }^{\circ} \mathrm{C}$ ). Quartz particles in the gasifier may crack at elevated temperatures (above $870^{\circ} \mathrm{C}$ ) associated with phase changes such as cristobalite formation. The non-silica components detected in the quartz particles in the present study may thus be inherited from inclusions in the original quartz grains, material introduced in conjunction with any such cracking, or contamination of the individual fields analysed by the surrounding glassy material. 
Although both potassium feldspar and anorthite (Ca-feldspar) were noted in the bulk coal gasification ash sample (Table 6), the feldspar crystals in the other heated stone and clinker samples were found to be essentially pure anorthite. As indicated in Table 6, most of the feldspars analysed have chemical compositions close to that of stoichiometric anorthite, which is $44.3 \% \mathrm{SiO}_{2}, 35.6 \% \mathrm{Al}_{2} \mathrm{O}_{3}$ and $20.1 \% \mathrm{CaO}$. A small concentration (up to around $0.5 \%$ ) of $\mathrm{Na}_{2} \mathrm{O}$ is also indicated in some cases, occurring in solid solution. Measurable concentrations of $\mathrm{Fe}_{2} \mathrm{O}_{3}, \mathrm{MgO}$ and $\mathrm{TiO}_{2}$ reported in some samples may represent inclusions within the feldspar crystals. The presence of anorthite crystals in clinker and heated stone samples may imply that the high temperature transformation products $(\mathrm{CaO}, \mathrm{MgO}$ and $\mathrm{FeO})$ of fluxing minerals (calcite, dolomite and pyrite) included in the carbon-rich particles reacted with the high temperature transformation products $\left(\mathrm{Al}_{2} \mathrm{O}_{3} \cdot 2 \mathrm{SiO}_{2}\right)$ of included kaolinite to form a CaO-, $\mathrm{MgO}$ - and FeO-bearing aluminosilicate melt, as the ash bed gravitated towards the hotter zone of the gasifier. According to Matjie et al. [1], the reducing conditions maintained by ferrous oxide and the higher temperatures in the carbon-rich particles enhance the molten phase formation. Some heated rock fragments with remnant pyrite, oxidized pyrite (pyrrhotite and $\mathrm{FeO}$ (wustite)), unreacted quartz and potassium feldspar grains, and unburned carbon particles are encapsulated by molten material [1]. On cooling the ash with steam injection at the bottom of the gasifier, anorthite and to a lesser extent mullite begins to crystallise out from the melt. It is suggested that the rock fragments act as sites of heterogenous nucleation, initiating anorthite crystallisation. As the remnant molten materials cool on the rotating grate at the bottom of the gasifier, a $\mathrm{CaO}$ - and $\mathrm{FeO}$-bearing aluminosilicate glass is formed on solidification of the melt.

Potassium feldspar, in the form of microcline, is commonly present in the non-coal rocks associated with South African coal seams [18]. The potassium feldspar noted in the bulk coal gasification ash (Table 6) may thus represent residual particles originally of detrital origin. The euhedral shape of the anorthite crystals (Fig. 4, top right), however, and their textural relationship to the associated glassy matrix, suggest that most of the anorthite crystals formed in the gasification ash from the molten state, in a manner analogous to the crystallisation of igneous rocks from magmatic materials. The textural features suggest 
that melting and subsequent crystallisation has taken place, and that solid-state reactions resulting in feldspar formation, identified in combustion-based studies [23], [22], [24] and [25] are less significant in the fixed-bed gasification process.

Because of its high melting point, anorthite is the first feldspar mineral to form during crystallisation of igneous rocks, crystallising from silicate magmas at around $1550{ }^{\circ} \mathrm{C}$ [26]. This is consistent with its occurrence in the clinkers of the present study. The abundance of $\mathrm{CaO}$ in the feed coal ash (Table 2), relative to $\mathrm{Na}_{2} \mathrm{O}$ or $\mathrm{K}_{2} \mathrm{O}$, suggests that significant quantities of anorthite would be able to form from the melt developed in the gasifier before the composition of the liquid phase could change, as a consequence of $\mathrm{Ca}$ feldspar crystallisation, to the point where a more sodium-rich feldspar mineral might start to crystallise from the melt instead.

\subsubsection{Aluminosilicate glass}

The aluminosilicate glass in the coal gasification ash and clinker samples, as determined by electron microprobe analysis (Table 6), varies considerably among the samples studied. Based on averages for a number of individual points, the proportion of $\mathrm{SiO}_{2}$ in the glass ranges from around $20 \%$ to around $70 \%$ and $\mathrm{Al}_{2} \mathrm{O}_{3}$ from $15 \%$ to $35 \%$. High $\mathrm{Si}$ content in the glass may contribute significantly to pozzolanic reactions in the production of gasification ash-bricks and cement concrete. The reactive $\mathrm{Si}$ in the glass may react with excess $\mathrm{CaO}$ from cement phases, in the presence of water, to further enhance strength development in cement-bonded products such as ash-bricks and concrete. Although one or two samples have higher values, the proportion of $\mathrm{Fe}_{2} \mathrm{O}_{3}$ in the glass is mostly less than $10 \%$ and $\mathrm{CaO}$ mostly less than $5 \%$. $\mathrm{MgO}, \mathrm{TiO}_{2}$ and $\mathrm{K}_{2} \mathrm{O}$ are also significant components of the glass in a number of the samples studied.

Fig. 5 indicates the correlation between the proportions of the main oxides in the aluminosilicate glass for each sample, based on averaging a number of points as indicated in Table 6, and the proportions of the same oxides inferred from the bulk chemistry of each sample and the quantitative XRD data (Table 4). Although there is considerable scatter, the overall trend for $\mathrm{SiO}_{2}, \mathrm{Fe}_{2} \mathrm{O}_{3}$ and $\mathrm{CaO}$ suggests a positive correlation, with 
many of the individual points falling close to the diagonal representing equality for the two different types of evaluations. The overall trend for $\mathrm{Al}_{2} \mathrm{O}_{3}$, however, seems to be almost the opposite, with a negative correlation; notwithstanding this apparent trend, over half of the points still fall close to the equality line.
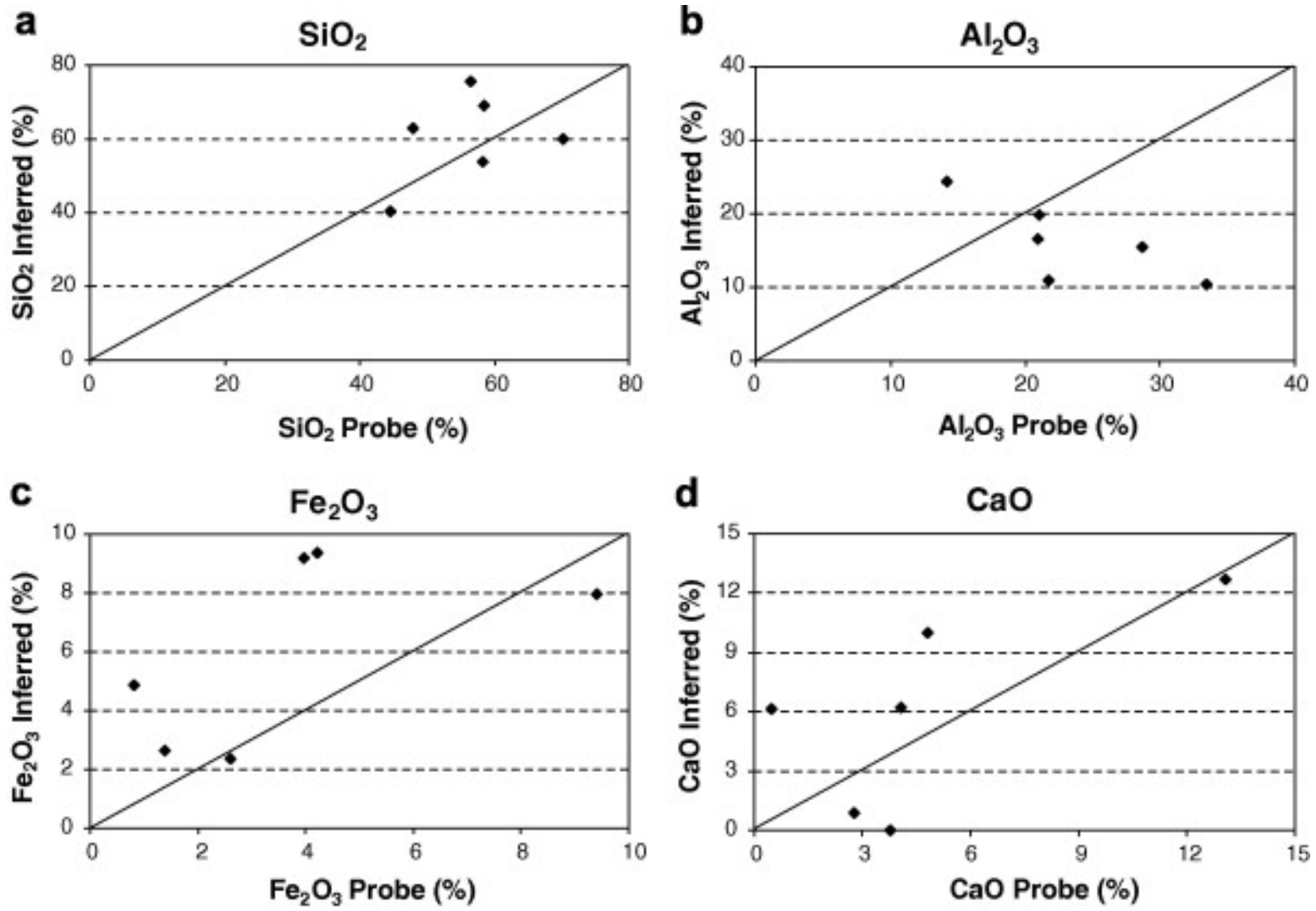

Fig. 5. Correlation between key oxide percentages in aluminosilicate glass as determined by electron microprobe analysis (Table 6) and inferred percentages of same oxides in glass fraction interpreted from bulk composition and XRD analysis (Table 4): (a) $\mathrm{SiO}_{2}$; (b) $\mathrm{Al}_{2} \mathrm{O}_{3} ;$ (c) $\mathrm{Fe}_{2} \mathrm{O}_{3} ;$ (d) $\mathrm{CaO}$.

\subsubsection{Other particles and phases}

A range of other particles and glassy phases is also present in the samples, and the composition of some of these is indicated in Table 7. They include particles identified as corundum, with almost $100 \% \mathrm{Al}_{2} \mathrm{O}_{3}$, and particles, probably representing rutile or anatase, that consist almost entirely of $\mathrm{TiO}_{2}$. Small proportions of $\mathrm{SiO}_{2}$ and/or $\mathrm{Al}_{2} \mathrm{O}_{3}$ in some particles may represent inclusion of glass or other phases in the analysed field. Other phases, with roughly equal proportions of $\mathrm{SiO}_{2}$ and $\mathrm{Al}_{2} \mathrm{O}_{3}$ have been tentatively 
identified as metakaolin, probably derived from kaolinite in the feed coal. Although mullite is identified in the various materials by XRD, the lack of contrast between this mineral and the associated aluminosilicate glass makes it difficult to identify and analyse the mullite composition separately by microprobe techniques. The individual mullite crystals are also likely to be sub-micron in size, so that the spot size embraced in any microprobe analysis would inherently include at least some of the associated glassy matrix as well.

Table 7.

Composition of other coal gasification ash components (wt $\%)$ as determined by electron microprobe

\begin{tabular}{|c|c|c|c|c|c|c|c|c|c|c|c|c|c|}
\hline & Pts & $\mathrm{SiO}_{2}$ & $\mathrm{TiO}_{2}$ & $\mathbf{A l}_{2} \mathbf{O}_{3}$ & $\mathrm{Fe}_{2} \mathrm{O}_{3}$ & MgO & MnO & $\mathrm{CaO}$ & $\mathrm{Na}_{2} \mathrm{O}$ & $\mathbf{K}_{2} \mathbf{O}$ & $\mathbf{P}_{2} \mathbf{O}_{5}$ & $\mathrm{SO}_{3}$ & Total \\
\hline \multicolumn{14}{|l|}{ Corundum } \\
\hline Clinker 8 & 2 & 0.03 & 0.00 & 99.02 & 0.19 & 0.00 & 0.01 & 0.07 & 0.00 & 0.00 & 0.00 & 0.03 & 99.36 \\
\hline \multicolumn{14}{|c|}{ Metakaolin } \\
\hline Clinker 8 & 5 & 49.57 & 0.50 & 42.08 & 0.87 & 0.17 & 0.00 & 0.11 & 0.34 & 0.35 & 0.08 & 0.06 & 94.13 \\
\hline \multicolumn{14}{|l|}{ Ti-oxide } \\
\hline Clinker 7 & 2 & 2.84 & 93.33 & 0.77 & 0.19 & 0.02 & 0.01 & 0.07 & 0.02 & 0.08 & 0.02 & 0.01 & 97.37 \\
\hline $\begin{array}{l}\text { Clinker } \\
10\end{array}$ & 3 & 11.61 & 82.81 & 4.23 & 0.62 & 0.15 & 0.02 & 0.14 & 0.14 & 0.69 & 0.08 & 0.03 & 100.50 \\
\hline $\begin{array}{l}\text { Heated } \\
\text { stone } 3\end{array}$ & 1 & 0.19 & 98.21 & 0.19 & 0.17 & 0.00 & 0.00 & 0.00 & 0.01 & 0.03 & 0.00 & 0.00 & 98.78 \\
\hline \multicolumn{14}{|c|}{ Al-phosphate } \\
\hline Clinker 9 & 6 & 3.89 & 0.13 & 24.18 & 0.52 & 1.75 & 0.02 & 26.13 & 0.45 & 2.41 & 27.39 & 0.01 & 86.88 \\
\hline \multicolumn{14}{|c|}{$\mathrm{Fe}-\mathrm{Mg}$-rich } \\
\hline Clinker 2 & 1 & 13.05 & 13.66 & 6.10 & 59.27 & 3.84 & 0.44 & 1.85 & 0.26 & 1.07 & 1.33 & 0.29 & 101.14 \\
\hline Clinker 8 & 5 & 0.38 & 47.45 & 0.27 & 49.45 & 2.05 & 0.75 & 0.59 & 0.02 & 0.10 & 0.04 & 0.17 & 101.27 \\
\hline Clinker 9 & 2 & 1.01 & 1.06 & 23.09 & 68.05 & 8.01 & 0.07 & 0.11 & 0.01 & 0.03 & 0.05 & 0.00 & 101.49 \\
\hline $\begin{array}{l}\text { Clinker } \\
10\end{array}$ & 9 & 40.23 & 3.60 & 10.00 & 23.33 & 15.06 & 0.30 & 4.77 & 0.27 & 0.75 & 2.08 & 0.28 & 100.66 \\
\hline & Pts & $\mathrm{Si}$ & $\mathrm{Ti}$ & $\mathrm{Al}$ & $\mathrm{Fe}$ & $\mathrm{Mg}$ & $\mathrm{Mn}$ & $\mathrm{Ca}$ & $\mathrm{Na}$ & K & $\mathrm{P}$ & S & Total \\
\hline
\end{tabular}




\begin{tabular}{|c|c|c|c|c|c|c|c|c|c|c|c|c|c|}
\hline & Pts & $\mathrm{SiO}_{2}$ & $\mathrm{TiO}_{2}$ & $\mathrm{Al}_{2} \mathrm{O}_{3}$ & $\mathrm{Fe}_{2} \mathrm{O}_{3}$ & MgO & MnO & $\mathrm{CaO}$ & $\mathrm{Na}_{2} \mathrm{O}$ & $\mathbf{K}_{2} \mathbf{O}$ & $\mathbf{P}_{2} \mathbf{O}_{5}$ & $\mathrm{SO}_{3}$ & Total \\
\hline \multicolumn{14}{|l|}{ Pyrrhotite } \\
\hline Clinker 8 & 4 & 3.50 & 0.04 & 0.01 & 55.44 & 0.48 & 0.03 & 0.33 & 0.02 & 0.01 & 0.04 & 28.76 & 88.66 \\
\hline $\begin{array}{l}\text { Heated } \\
\text { stone } 3\end{array}$ & 4 & 0.01 & 0.03 & 0.05 & 62.49 & 0.00 & 0.02 & 0.01 & 0.00 & 0.01 & 0.00 & 38.70 & 101.32 \\
\hline
\end{tabular}

An aluminophosphate phase is also indicated by the microprobe data. Although departing from the stoichiometric composition of crandallite $\left(13.6 \% \mathrm{CaO}, 37.1 \% \mathrm{Al}_{2} \mathrm{O}_{3}, 34.0 \%\right.$ $\mathrm{P}_{2} \mathrm{O}_{5}, 15.3 \% \mathrm{H}_{2} \mathrm{O}$ ), this material probably represents a product of the gorceixite-group material identified in the LTA of the feed coal (Table 1).

A range of phases rich in iron and magnesium are also indicated in Table 7. Some of these may represent discrete hercynite $\left(\mathrm{FeAl}_{2} \mathrm{O}_{4}\right)$ or ferrianspinel $\left((\mathrm{Fe}, \mathrm{Mg}) \mathrm{Al}_{2} \mathrm{O}_{4}\right)$ phases, while others, such as in Sample Clinker 10, represent Fe-Mg silicate components, apparently occurring in a more glassy form. The Fe-Mg silicate minerals in the clinkers analysed in this study may have been derived from reactions between fluxing minerals (pyrite, calcite and dolomite) and kaolinite or illite at elevated temperatures during coal gasification. During the burning of pyrite in the presence of carbon, iron can be produced. The iron may react with inorganic elements or substances to form a spinel, such as magnesioferrite $\left(\mathrm{MgFe}_{2} \mathrm{O}_{4}\right)$, which dissolves in the melt formed from the decomposition products of kaolinite, calcite and pyrite at $750-750{ }^{\circ} \mathrm{C}$ to form $\mathrm{Fe}-\mathrm{Mg}$ silicate glass [8]. Phases consisting of iron and sulphur are also present, with a composition close to that of pyrrhotite $(\mathrm{FeS}, 63.6 \% \mathrm{Fe}, 36.3 \% \mathrm{~S})$ rather than pyrite $\left(\mathrm{FeS}_{2}, 46.6 \% \mathrm{Fe}, 53.4 \% \mathrm{~S}\right)$. These are probably reaction products of pyrite in the original feed coal. Under reducing conditions, such as those developed during gasification, pyrite decomposes at a temperature of around $700{ }^{\circ} \mathrm{C}$ to form pyrrhotite and $\mathrm{S}_{2(\mathrm{~g})}[3]$ and [27].

\section{Conclusions}

Integration of XRD, chemical analysis, optical microscopy and electron microprobe studies has provided an improved basis for understanding the nature and origin of the bulk gasification ash and clinker components produced by fixed-bed gasification, 
including the links between the mineral matter in the feed coal and the various gasification ash and clinker constituents.

The bulk gasification ash, heated stone and clinker samples produced by the gasification process contain fragments of heat-altered rock materials, set in an often vesicular, partly crystalline glassy matrix. Quartz and possibly K-feldspar in the feed coal or admixed non-coal rocks may pass unaltered into the bulk gasification ash, along perhaps with titanium or iron-titanium oxides and aluminophosphate minerals. Pyrite also reacts to form pyrrhotite as part of the gasification process. Although products of solid-state reactions may be preserved in some of the heat-altered fragments, anorthite that has crystallised from molten aluminosilicate material is contained within a glassy matrix in a manner analogous to the formation of igneous rocks.

Rietveld-based X-ray diffraction can be used to quantify the proportions of the different minerals, and also the amorphous glass, in coal gasification ash and clinkers, and relate these to the minerals in the feed coal as determined by similar analysis of the oxygenplasma ash residues. The chemical composition of the amorphous or glassy phase in each material can also be estimated by proportioning techniques from the XRD results and bulk chemical analysis data. Comparison to the results of electron microprobe analysis indicates that, although some scatter is involved, the relative proportions of the main elements in the aluminosilicate glass are broadly similar to those estimated from the XRD data and the bulk chemical composition. The XRD and electron microprobe results indicate that coal gasification ash analysed in this study contains a significant proportion of non-crystalline glass. The reactive $\mathrm{Si}$ species in the glass may react with excess $\mathrm{CaO}$ from cement phases and water to further enhance strength development of cementbonded products such as ash-bricks and concrete. 


\section{References}

[1] R.H. Matjie, C. Van Alphen and P.C. Pistorius, Mineralogical characterization of Secunda gasifier feedstock and coarse ash, Miner Eng 19 (2006), pp. 256-261.

[2] C.R. Ward, Analysis and significance of mineral matter in coal seams, Int J Coal Geol 50 (2002), pp. 135-168.

[3] Bryers RW. Influence of segregated mineral matter in coal. In: Vorres K, editor. Mineral matter and ash in coal, Symposium of American Chemical Society; 1986. p. $351-74$.

[4] S. Srinivasachar, J.J. Helble and A.A. Boni, Mineral behaviour during coal combustion. 1. Pyrite transformations, Prog Energy Combust Sci 16 (1990), pp. 281-292. [5] S. Srinivasachar, J.J. Helble, A.A. Boni, N. Shah, G.P. Huffman and F.E. Huggins, Mineral behaviour during coal combustion. 1. Illite transformations, Prog Energy Combust Sci 16 (1990), pp. 293-302.

[6] Attalla MI, Morgan S, Riley K, Bryant G, Nelson PF. Trace element deportment in combustion processes. Research report 50, Cooperative Research Centre for Coal in Sustainable Development (CCSD), CSIRO, University of Newcastle, Macquarie University, Australia; 2004.

[7] Van Alphen C. Factors influencing fly ash formation and slag deposit formation (slagging) on combusting a South African pulverized fuel in a 200 MWe boiler. Ph.D. Thesis, The Faculty of Engineering and the Built Environment, University of the Witwatersrand, Johannesburg; 2005.

[8] Briggs DL, Lindsay CG. High-temperature interactions among minerals occurring in coal. In: Vorres K, editor. Mineral matter and ash in coal, Symposium of American Chemical Society; 1986. p. 128-37.

[9] H.E. Schwiete and M.A. Dolbor, Forchungsbericht des Landes, Nordrhein, Westfalen (1983) p. 1186.

[10] Demoulian E, Gourdin P, Hawthorn F, Vernet C, editors. Proceedings of seventh international congress on the chemistry of cement, Paris, vol. 2, no. III; 1980. p. 89-94. [11] C.R. Ward and D. French, Determination of glass content and estimation of glass composition in fly ash using quantitative X-ray diffractometry, Fuel 85 (2006), pp. 22682277. 
[12] Bunt JR. A new dissection methodology and investigation into coal property transformational behaviour impacting on a commercial-scale Sasol-Lurgi MKIV Fixed Bed gasifier. Ph.D. thesis, University of North-West, Potchefstroom, Chapter 2; 2006. [13] J.H. Patterson, J.K. Corcoran and K.M. Kinealy, Chemistry and mineralogy of carbonates in Australian bituminous and sub-bituminous coals, Fuel 73 (1994), pp. 17351745.

[14] J.C. Taylor, Computer programs for standardless quantitative analysis of minerals using the full powder diffraction profile, Powder Diffr 6 (1991), pp. 2-9.

[15] K. Norrish and B.W. Chappell, X-ray fluorescence spectrometry. In: J. Zussman, Editor, Physical methods in determinative mineralogy, Academic Press, London (1977), pp. 201-272.

[16] H.J. Gluskoter, Electronic low-temperature ashing of bituminous coal, Fuel 44 (1965), pp. 285-291.

[17] C.R. Ward, C.E. Matulis, J.C. Taylor and L.S. Dale, Quantification of mineral matter in the argonne premium coals using interactive Rietveld-based X-ray diffraction, Int $J$ Coal Geol 46 (2001), pp. 67-82.

[18] K.L. Pinetown, C.R. Ward and W.A. van der Westhuizen, Quantitative evaluation of minerals in coal deposits in the Witbank and Highveld coalfields and the potential impact on acid mine drainage, Int J Coal Geol 70 (2007), pp. 166-183.

[19] C.R. Ward, D.A. Spears, C.A. Booth, I. Staton and L.W. Gurba, Mineral matter and trace elements in coals of the Gunnedah Basin, New South Wales, Australia, Int J Coal Geol 40 (1999), pp. 281-308.

[20] In: C.R. Ward, Editor, Coal Geology and Coal Technology, School of Applied Geology, University of New South Wales/Blackwell Scientific Publications, Australia/Melbourne, Oxford, London (1984), pp. 40-113.

[21] E. Raask, Creation, capture and coalescence of mineral species in coal flame, $J$ Inst Energy 57 (1984), pp. 231-239.

[22] French D, Dale L, Matulis C, Saxby J, Chatfield P, Hurst HJ. Characterization of mineral transformations in pulverized fuel combustion by dynamic high-temperature $\mathrm{X}$ ray diffraction analyzer. In: Proceedings of 18th Pittsburgh international coal conference, Newcastle, Australia, December (CD-ROM); 2001.7 pp. 
[23] Benson SA. Laboratory studies of ash deposit formation during the combustion of Western U.S. coals. Ph.D. Thesis, The Pennsylvania State University; 1987.

[24] B. Jung, Sintering characteristics of low-rank coal ashes, Korean J Chem Eng 13 (6) (1996), pp. 633-639.

[25] A.P. Reifenstein, H. Kahraman, C.D.A. Coin, N.J. Calos, G. Miller and P. Uwins, Behaviour of selected minerals in an improved ash fusion test: quartz, potassium feldspar, sodium feldspar, kaolinite, illite, calcite, dolomite, siderite, pyrite and apatite, Fuel $\mathbf{7 8}$ (1999), pp. 1449-1461.

[26] W.A. Deer, R.A. Howie and J. Zussman, Rock-forming minerals, Framework silicates vol. 4, Longman, London (1963), p. 435.

[27] Y.Y. Chuang, K.C. Hsieh and Y.A. Chang, Thermodynamics and phase relationships of transition metal-sulphur systems - Part V: a re-evaluation of the Fe-S system using an associated solution model for the liquid phase, Metall Trans Ser B 16B (1985), pp. 277-285.

Corresponding author. Address: Sasol Technology (Pty) Ltd., P.O. Box 1, Sasolburg, Free State 1947, South Africa. 